\title{
IMPACT ANALYSIS OF THE USE OF DINAR IN MONETARY TRANSACTIONS
}

\author{
ANALISIS DAMPAK PENGGUNAAN DINAR DALAM TRANSAKSI MONETER \\ A. Alhifni1; R. Trihantana ${ }^{2}$ \\ ${ }^{1}$ Sekolah Pascasarjana Universitas Airlangga, Jl. Airlangga 4-6, Surabaya - 60286/Program \\ Studi Perbankan Syariah Fakultas Ekonomi Islam Universitas Djuanda, Jl. Tol Ciawi No. 1, \\ Kotak Pos 35 Bogor 16720, alhifniui@gmail.com \\ 2Program Studi Perbankan Syariah Fakultas Ekonomi Islam Universitas Djuanda, Jl. Tol \\ Ciawi No. 1, Kotak Pos 35 Bogor 16720, rully.trihantana@unida.ac.id
}

\begin{abstract}
The purpose of this research was to determine the monetary impact of the use of the Dinar in the transaction, monetary policy is a policy adopted by Indonesia in regulating the financial supply or regulate the amount of money in circulation. In Islam, the monetary policy should be balanced between the IS and LM curves in order to avoid inflation. Dinar and Dirham eligible to be used as a means of transaction for two coins have a value and a stable element. The method used is content analysis method. The results of this study explains that the use of the Dinar as the currency can be implemented because it has the feasibility to stabilize the course of monetary although the application of the Dinar is not a major step in managing monetary in a country because of the limited reserves of gold, and when the Dinar could be applied monetary impact will be more stable because can balance the IS and LM.
\end{abstract}

Keywords: Impact of Monetary, Dinar

\begin{abstract}
ABSTRAK
Tujuan dari penelitian ini adalah untuk menentukan dampak moneter dari penggunaan Dinar dalam transaksi, kebijakan moneter adalah kebijakan yang diadopsi oleh Indonesia dalam mengatur pasokan keuangan atau mengatur jumlah uang yang beredar. Dalam Islam, kebijakan moneter harus seimbang antara kurva IS dan LM untuk menghindari inflasi. Dinar dan Dirham memenuhi syarat untuk digunakan sebagai alat transaksi selama dua koin memiliki nilai dan unsur yang stabil. Metode yang digunakan adalah metode content analisis. Hasil penelitian ini menjelaskan bahwa penggunaan Dinar sebagai mata uang yang dapat diimplementasikan karena memiliki kelayakan untuk menstabilkan jalannya moneter meskipun penerapan Dinar bukanlah langkah besar dalam mengelola moneter di negara karena terbatasnya cadangan emas, dan dampak moneter ketika Dinar bisa diterapkan akan lebih stabil karena dapat menyeimbangkan IS dan LM.
\end{abstract}

Kata kunci: Dampak Moneter, Dinar 
Alhifni, Anas. 2016.Impact Analysis Of The Use Of Dinar In Monetary Transactions. Jurnal Syarikah 2 (2). Hal 267-278. 


\section{INTRODUCTION}

Gold (Dinar) once the currency that is used throughout the world, and were more stable during several century, because of its nominal value in accordance with the value of intrinsic. The emergence of fiat money as a currency and the many people who melted gold into jewelry made of gold no longer be used as currency. Indonesia is one country that uses fiat money (IDR). Fiat money is money that is not propped up with and cannot be exchanged functions with gold or anything of value (ISRA, 2015, Jamaluddin, 2013 ).

Rupiah currency as a medium of exchange in Indonesia, arranged through monetary policy set by the Bank of Indonesia. The objective of the monetary policy to maintain a balance among the internal (economic growth, price stability, the stability of inflation and equitable development) and external (balance of the balance of payments). In the implementation of monetary policy is not necessarily to walk easily and according to plan but often and almost always have a difficult problem. Monetary policy in Indonesia is very bad because the control of money supply is not good, the Rupiah depreciating, the use of interest rate system, the amount of money circulating in the community, but not channeled to the goods market (real sector) and so forth so that increasing amount of inflation (Hussain, 2010).

Indonesia will continue to be in a slump if the issue is not resolved. One solution that can be taken is to re-use Dinar as a means of payment and transactions. Dinar and Dirham currency is derived from the gold and silver corresponding nominal amount and intrinsic so that the level of liquidity and balance can be maintained.
There are two factors that cause the economic crisis Indonesia and other countries. First, the currency issue where value is tied to another country's currency (IDR against USD), is not in itself so that the value is not stable. If the USD currency fluctuation, it will definitely affect the stability of the other currencies. Second, the fact that money is no longer used as a medium of exchange, but also, as a traded commodity (in foreign exchange) and taken advantage (derived from interest or usury) on each transaction borrower or deposit money (ISRA, 2015). Therefore, the use of the Dinar and Dirham as currency can be used as an alternative, although it must be order and monetary mechanisms when the Dinar and Dirham applied, and should see gold reserves in Indonesia. Based on the formula above issues can be made following theresearch, first the extent to which the use of the Dinar in the current transaction. Secound the possibility to replace the Dinar currency Rupiah. Third about a sharia monetary operations when it uses the Dinar. Fourth, the examples of countries or Dinar thorough application and the last one about Sin usury anything that can be eliminated with the Dinar.

\section{LITERATUR REVIEW AND RESEARCH METHODS}

Money is a tool that is used as a means of payment in the transaction. In the Islamic concept of money is a means to transact and exchange tool. Seigniorage is the difference between the intrinsic value and the nominal value of money. Dinar currency is the currency used by several countries in the form of gold used since the seventh century BC. Dinar eligible to be used as a means of transaction for two coins have a value and a stable element. While the Dirham is derived from the 
language of the people Sassan in Persian is "drachms". Based on the results of research conducted by Muhammad Bahr Ilmi on feasibility analysis Dinar and Dirham as a transaction currency against Indonesia states that in carrying out the role and function of the economy, the government of Indonesia can apply Dinar and Dirham currency as a means of transaction. Differences Rupiah or Dinar banknotes is not immune to the financial crisis, the paper money is steadily increasing but its value would be diminished. While the Dinar and Dirham immune to the financial crisis and limited resources but its value will continue to rise. (ISRA, 2015)

The method used in this research is the method of content analysis. According Bungin and Creswel (2007, 1994) techniques are used to create inferences replicable, and authentically with regard to the context. In this study, the content is taken from the results of research that has been there before, especially with regard to the Dinar and monetary, then studied in depth, and then made a conclusion tailored to the theme in this study.

\section{DISCUSSION}

\section{The Extent To Which The Use of The Dinar In The Current Transaction}

Dinar has been used since the early days of the Islamic empire. Dinar is not derived from the Arabic language, but from the Greek and is another word of AramaicPersian "denarius". While the Dirham is derived from the language of the people Sassan in Persian is "drachms". At first the Dinar and Dirham printed by people persia. Dinar and Dirham during the reign of Caliph Umar Bin Khattab was introduced as a means of transaction and currency standards that apply throughout the lands of Islam. Dirham printed first by the government of Caliph Abdul Malik bin Marwan in 695 AD (ISRA, 2015). As in Shabri (2006) Caliph Abdul Malik bin Marwan Al-Hajjaz direct to print Dirham with 10 Dirham which has the same price at 7 Dinars. Development tools such transactions is very good, so it has been universally recognized, and believed to be the unit of exchange of good tool for debt repayment, investment and savings in some states in the world.

A history of the Dinar and Dirham revealed that the Dinar and Dirham fade away during the reign of the Ottoman sultanate collapse. So at that time European countries publishing unit exchange tool in the form of cash with the grades were flat, but the value of money is not supported in the availability of reserves or commodity like gold. Then the medium of exchange value is uncertain and dependent on the issuance of money. So this provides a great opportunity for those in the money market to manipulate that can cause prolonged monetary crisis.

At the time of the Prophet Muhammad, Dinar and Dirham is used as the official currency of the country. Because it is always stable and in accordance with the amount of gold content so that it is unlikely to depreciate in value. But at the present time, the use of the Dinar to be fading even classified as disappeared and turned into fiat money. It is not spared from significant events that changed the global economic system that is Bretton Woods. Bretton Woods is a collaboration between the United States and Britain, held as a result of the existence of an economic instability. Finally, the conference was held and resulted in a change in the global economic order that originally all based on the country's gold reserves turned into Dollars. 
This is indeed the US tactics in tackling the problems that occur because of the gold reserves held by the United States is getting low.

Therefore, the use of the Dinar is more faded and disappeared. The use of the Dinar was hardly noticeable because everyone was focused on the Dollar. Whereas Dollar cause a lot of imbalances in economy not like when the gold is still the standard for every country.

Hoist back into gold and silver are called by various circles in the world, in fact, especially non-Muslims. Muslims should be much more advanced and obviously, because it has the Dinar and Dirham. With the Dinar and Dirham wealth will be evenly distributed to all parties. This movement will continue, will not stop, and could not be stopped. Those who do not follow it, or reject it, be crushed by the wheel of history and fitra. (Saidi, 2016)

Discussions to replace fiat currencies into gold Dinar currency began so conversation everywhere. Even some regions have been using the gold Dinar as currency although still small in scope. Some data about the trip Dinars in order to be accepted as a world currency. (Hamidi, 2007):

1. 1992. Granada, Spain. Dinar-Dirham reprinted by the Islamic Mint Spain under the authority of the Islamic World Trading Organization (Wito). Made of 4.25 grams of 22 carat gold and sterling silver Dirham (95\%) 2,975 grams.

2. In 1995. Turkey. Prof. 'Umar Ibrahim Vadillo, the initiator and founder of present Wito-Dirham Dinar before Dr. Necmettin Erbakan who was a minister then declared the Dinar will be used as the national currency.
3. 1998. Universiti Sains Malaysia, Penang. Gold Dinar and silver Dirham was discussed in the Political Economy of International Islamic Conference (IIPEC) 3rd officiated by Tun Daim Zainuddin, who later served as Minister of Finance. In the face of Muslim American Social Scientist, Imad-ad-Dean Ahmad of the Minaret of Freedom Institute convey important messages in monetary Islamic Dinar.

4. 2000. Indonesia. Dinar and Dirham first reprinted in the archipelago by fuqara shadilliya-darqawiyya (Achmad Adjie Amir, Amir Abbas Malik Word and Muqaddem Abdalhaqq) and DinarDirham begin distributed through Islamic Mint Nusantara. These people are too spicy spread science and charity how to run Dinar-Dirham and overall structure, through ribats active in Jakarta and Bandung.

5. Year 2000 e-Dinar Ltd. A private institutions are legal entities that operate e-Dinar, established in Labuan, Malaysia. Then e-Dinar launched in IIPEC 4th, held Isnet-USM and was inaugurated by the Deputy Prime Minister of Malaysia. Now as many as 300,000 people from 160 countries have started using it.

6. June 25, 2001. Kuala Lumpur. When inaugurated the Al-Baraka Symposium 20th on Islamic Economics, Dr. Mahathir Mohamad declared the use of the gold Dinar as currency Muslims in Islamic Trading Bloc and as a national reserve of OIC member countries.

7. November 2001. Dubai. Islamic Mint officially launched gold Dinar and silver Dirham in the United Arab Emirates, and the audience can get in Thomas Cook Rostamani Exchange Company and Dubai Islamic Bank. In 
that occasion, 'Umar Ibrahim Vadillo stressed the need zakat paid by Dinar.

8. March 2002. Kuala Lumpur. Back one tidbit when Dr. Mahathir Mohamad claimed that Malaysia has provided a mechanism making use of the gold Dinar and means of payment in international trade.

9. May 2001. Kuala Lumpur. Prime Minister of Malaysia, Dr. Mahathir Mohamad, reiterated that Malaysia is exploring business use gold Dinar in trade with the three countries of West Asia, and Morocco, Libya and Bahrain have expressed interest. He also proposed the use of e-Dinar system to deal with the displacement in the form of physical gold in international payments and in terms of the bilateral agreement is required.

10. October 2002. The Chairman of PIRAC Ir. Zaim Saidi set up Wakala Adina in Jakarta. Earlier, we stand well-Wakala Islamic Mint Nusantara in Bandung and Jakarta Wakala Ribat. Wakala function of them as exchange booth where the public can buy and sell, swap and leave Dinar coin. Because of its function as a representative of the owner of DinarDirham, then it should not be lent Wakala Dinar-Dirham and give credit to third parties. Zaim Saidi is also known to be active write-Dinar Dirham in various media and fill a variety of seminars and discussions.

11.2004. Malaysia will use the gold Dinar as currency in bilateral trade between Malaysia and Iran.

Viewing the data above we can conclude that the gold Dinar has been gaining acceptance in the present era. Coupled with the issuance of fatwa on August 18, 1991 on the prohibition of the use of fiat entitled "Fatwa Concerning The
Islamic Prohibition of Using Paper Money as a Medium of Exchange", or "Fatwa On Prohibition of Use of Banknotes as a Tool of Change" led by Umar Vadillo. (Vadillo, 2001).

According to Iqbal (2016), brexit occurrence is evidence of the use of currency disposition Dinar and Dirham. Nature of gold (Dinar) and silver (Dirham) is like human nature that when you are in fear greatly, so that even an atheist would pray to God that he never knew, for help. The solution is simple, there is no crisis or we just use Dinar and Dirham whose name was mentioned in the Qur'an.

\section{Could Replace Dinar Currency Rupiah}

According Ilmi (2013) states that in carrying out the role and function of the economy, the government of Indonesia can apply Dinar and Dirham currency as a means of transaction. In principle the use of Dinar and Dirham not be the main solution to tackle the economic upheaval in Indonesia, there are many solutions that can be used by the government to tackle economic problems.

Dinar and Dirham eligible to be used as a means of transaction for two coins have a value and a stable element. Ibn Khaldun said in macroeconomic Islam, that a country will not be able to perform sustainable development without justice and the system was followed. This means that price stability has a guarantee of justice money in its function, so that the economy will be in a relatively stable condition.

Broadly speaking, the Dinar and Dirham has a role and a very important function in Indonesia, including :

1. Maintaining the stability of micro and macro economics

2. Maintain asset and or the real sector of the monetary system 
3. Become a modern economy functions with the gold standard

4. Addressing socioeconomic problems in society.

Shabri (2006), the Dinar and Dirham will not change its value although taken anywhere. Even if a pattern or picture is altered will not make it worth it to change. The stability of the Dinar and Dirham would deter speculative actions. Therefore, it can be seen in these days a lot of speculative actions, especially in the money market due to wear apart from the Dinar and Dirham. Shabri (2006), the use of the Dinar and Dirham will shut down all movement speculators to keep profits in the money market through arbitrage activity.

In addition to maintaining the stability of the economy, the use of the Dinar could reduce financial dependence on its users against the Dollar due to the inability in managing capital. When viewed closely, Muhammad (2010) states that have a balance of trade deficit is mostly Muslim country which means that funds from within the country more going abroad than foreign funds coming into the country itself. This leads to "capital flight" which is where a country has decreased foreign exchange (Saifuddin, 2015).

If this is the case, then the country will cover the budget deficit with debt financing. When he was talking about the debt it is certain that the country must meet the requirements posed by the country that gives debt. Moreover, the debt is paid with Dollars that will surely make the country increasingly choked because of the value of money is getting down and the amount paid will be even greater. That instability value of the Dollar. Unlike the gold is always the same until whenever.
Iswan (2008), The application of the Dinar in Indonesia strengthened by feasibility-feasibility Dinar and Dirham if used as currency :

1. Money is stable

Differences Dinar with fiat money is the stability of the money. Every Dinar containing 4.25 grams of 22 carat gold and there is no difference in the size of the contained gold Dinar in every country, there is no difference in the value of the Dinar is used in the country iraq Dinars used in saudi arabia. Dinar not have inflation so great since the days of the prophet until now, so the price of gold and the value of a constant and stable (Ibrahim, 2014)

2. Tool appropriate exchange

3. With the stable value and the same standards in each country, the Dinar will provide convenience and advantages for the public to make transactions both domestic and international transactions. Dinar is a currency of its own so it is not necessary to through the halal process and ratification as money, as opposed to fiat money which requires ratification in the form of law by the government that print

4. Reducing speculation, manipulation and arbitration

The same value of the Dinar in each country will reduce the level of speculation and arbitrage in the foreign exchange market, due to differences in the possibility of the exchange rate will be difficult. Fiat money or paper money to benefit speculators who seek profits. When the Dinar has become the single currency which is the same in every country, there will be no difference in the value of Dinar each 
country that provide benefits to the speculators.

5. Currency Ideal For International Trade.

Today almost all international trade transactions using fiat money. Not all types of fiat money can be used as a tool of international trade transactions because they are unstable or vulnerable to fluctuations. Countries that rarely use fiat money are developing countries.

However, Masduqi (2012) In practice there are two main things that led to the economic structure of the Islamic world to change so that the main reason for the application of the Dinar and Dirham currencies can not be implemented. First, the economic structure of the Islamic world is inseparable from the natural change factors, such as flooding, drought, prolonged rainy season, earthquakes and so on. Search history of Muslims until the mid-century classics performed by Muflih. Noting that at the time of imposition of currency Dinar and Dirham are strong indications of impending inflation caused by the impacts of climate change. The Jurist always show the simulated increase in food prices due to the natural factors. Second, destructive human behavior resilience Dinar and Dirham, because in the Islamic world still can not be separated from moral hazard.

History records in the world of Islam hoarding of foodstuffs, speculation, and currency counterfeiting. The destructive actions couses of shortages and rising prices. Both of these shows that history proves that at the time of application of the Dinar and Dirham currencies also occurred inflation. Third, the notion of Dinar and Dirham difficult to apply because it is not independent of these currencies against social unrest and other variables change.
Fourth, the structure of the contract will always be waiting for certainty about the stability of the currency is so slow the operational structure of the contract and the subsequent survival of greater economic interaction difficult to move quickly.

The difficulty in applying the Dinar and Dirham in Indonesia is having to change the economic order starting from the bottom back and it is one thing that somehow impossible. The effects of the monetary will take place between them:

1. The amount of money in circulation Iswan (2008), Indonesia's trade surplus gained through bilateral trade. Added gold reserves will affect the money supply through changes in the number of core money (monetary base). Money core is the obligation of the bank's monetary authority of Indonesia to the community or a commercial bank. Those money in the form of currency held by the public and bank.

2. The value of domestic Rupiah

Using Dinar as the support of the Rupiah is equal to the monetary system during the exchange value of gold in the period 1925-1931 and the Bretton Woods system in the years 1946-1971. At that time each country using gold as a standard means of exchange. Making the Dinar as the support of the Rupiah would limit the government to print the Rupiah in the amount of the excess. Because scored Rupiah will follow the amount of gold reserves owned by the government. Currently, the existing gold amounted to $100,000 \mathrm{~kg}$ in BI (Bank Indonesia) and 16 million $\mathrm{kg}$ in Papua.

Using Dinar reserves to prop up the Rupiah is not an ideal way to avoid the 
impact of the monetary system of fiat money today. But one thing to note here is that the crutch Rupiah with a Dinar will give a better effect than the Rupiah is not supported by any value. Failures and expiration of such systems caused by some countries that print money melebilhi gold reserves that they have that brought them to the economic collapse.

Components of the amount of money circulating in the community at large is presented as the monetary aggregate known as M1, M2, and so on. State whether Indonesia will replace the M1 alone or will replace M1 and M2 as well. Then, if the foreign exchange reserves held at this time sufficient to ensure the total nominal M1 and M2. Whether gold or silver that is owned by the state (in foreign exchange reserves or to be bought in the international gold market) available? If the answer is yes, the State of Indonesia when it also can replace Rupiah into Dinar and Dirham syar'i. It certainly with some assumptions, for example, there is no debt to be paid at the time, or there is no escape gold and silver abroad. If everything is adequate and available, the State Indonesia stayed print Dinar or Dirham syar'i, then the public is given a deadline to exchange their currency into Dinar and Dirham. This process is similar to what happens in the EU member states when almost simultaneously changing its currency to the Euro currency. The difference, in the State of Indonesia, the nominal value of money in circulation (both the M1 and M2) are secured and backed up by gold or silver whose value is equivalent to the amount of money in circulation and deposited in the state treasury as a backup (guaranteed); while the Euro, together with the US Dollar, the form of fiat money, namely the lump of paper by the government are considered as legal tender and the public are required to accept it as payment/transaction that has a certain value. That is, countries that are currently available (including Indonesia) who embrace fiat money can print as much as any paper currency and with any nominal value without being backed up by collateral of gold or silver. Of course, at one point, and certain circumstances, this legal tender will collapse and heaps Rupiah or Dollar even be equal in value to a stack of plain paper trash.

Thus, the Indonesian State efforts to have the availability and adequacy of reserves must be started now, namely by preventing runaway gold or silver abroad. Practical steps were able to maintain and increase the availability of gold or silver, among others (Hizbut, 2008):

1. State-Muslim countries today have to reduce or even stop imports of foreign goods. Therefore, it only resulted in capital flight out of the country (in the form of gold/silver and foreign currencies).

2. Increasing exports abroad, with payment in the form of gold/silver or foreign currency used for payment of imports (if the country still imports on certain commodities indispensable).

3. Stop and take over mining companies (including gold and silver) were concessioned to foreigners. By doing so, the state that will produce, control, and make it as reserves to back-up the issuance of Dinar and Dirham syar'i.

4. State impose any trade transactions with foreign countries to use a standard Dinar and Dirham (or currency based on gold and silver metal). In this case, the State Indonesia can obtain capital gains of gold and silver from a strategic commodity 
payments required by the international community, such as oil.

Based on this description, there may be a country to implement and change their currency into Dinar and Dirham syar'i, unless the state is able to counter the hegemony of political, economic, and military superpowers today, especially the US. That means, the desire to change the currency of the Islamic countries that there is currently a Dinar and Dirham syar'i based metals gold and silver (the same nominal value and intrinsic) must be accompanied by a strong desire of Muslims to have a great country, powerful in the world, as well as Indonesia. Syar'i monetary system (including currency Dinar and Dirham syar'i) will not be successfully realized in a country mired by the domination of the capitalist economy and highly dependent on the strength of the global economy (especially the economies of Western country).

Based on the science and application of scholars once complete eminent economists previous five centuries of the Islamic world that Ibn Taymiyyah (12631328). To be able to change the currency into Dinars and Dirhams, then Ibn Taymiyah formulate the equation of exchange as follows (Iqbal, 2016) :

1. The amount of money (money that is lower than the Dinar and Dirham as copper) can only be printed in proportion to the number of transactions in such a way so as to guarantee a fair price. Rulers should not print money excessively detrimental to society because of the destruction of the purchasing power of existing money in them ".

2. For the Dinar and Dirham excluded from the formulation of Ibn Taymiyah as the object itself (gold and silver), which will limit the volume availability in the community. By itself Gold and Silver Dirham or Dinar and will always be a fair money because the volume is not controlled by the authorities.

Without the concept and the stages are clear, great ideals and palpable, and the hard work and tireless struggle, accompanied by the readiness of Muslims to sacrifice it wishes it could not have materialized. The problem for us now is just choose one of two paths, if we just want to dream under the heel of capitalism is filled with dirt and filth, or struggle, sacrifice, and work hard to realize the laws of Allah. through the establishment of the State of Indonesia ar-Rasyidah who follow manhaj Prophet.

\section{Monetary Operations When It Replaces Dinar}

Monetary policy is a policy adopted by Indonesia in regulating the financial supply or regulate the amount of money in circulation. Monetary associated with the LM curve (Liquidity Money). In Islam, the monetary policy should be balanced between the IS and LM curves in order to avoid inflation. If the government prints money, then the money should be channeled to the real sector, should not only be distributed to the money market, because if it did so then the IS and LM curves will not be balanced. But in fact, this time the movement of the LM curve faster than the movement of the curve Is, because the government just print money being offset by movements in the market of goods, thus causing inflation.

Therefore, the government's policy of printing money should be in accordance with the needs in the freight market. Not only in Indonesia, sharia theory is merely a theory, but in other countries also experienced the same thing, namely the 
phenomenon of monetary inflation (inflation is a monetary phenomenon). Inflation will continue to happen when the government is implementing monetary policy with interest-based.

In sharia monetary operations are an instrument to balance the IS and LM curves, namely by issuing sukuk. With sukuk, the government can attract investors to obtain funds that the result will be distributed to the real sectors or markets goods without having to print money back. Thus, the IS and LM curves can move together in accordance with sharia. Islamic monetary operation was conducted because of the imbalance of the IS and LM and the effect of the use of the currency whose value is small and does not correspond to the existing gold reserves. Imbalance IS and LM make the economy unstable, causing inflation. When the Indonesian state using the Dinar and Dirham currency as the Islamic monetary operations remain because it was a precaution and the country still requires instruments in advancing the development of a country (Haerisma 2011, Harahap, 2014).

\section{Examples Of Countries That Apply Dinar}

Countries that implement the Dinar as a means of transaction such as:

1. Malaysia

Yacoob, et al (2011), Forging Malaysia's first gold Dinar was conducted by The Royal Mint of Malaysia. Gold Dinar Royal Mint launched on the 28th of July 2003 in Shah Alam (Dahinden, 2008). In addition, on May 21, 2006 Kelantan Gold Dinar has been launched and he was forged by Mariwasa Kraftangan Sdn Bhd. The use of the Dinar is as follows; as currency and electronic payment transactions (e-Dinar and
Web Dinar), payment of zakat, hajj affairs, resurfacing, savings, gifts and as conducting marriage.

Mahatir Muhammad stated that Malaysia provides a mechanism of gold Dinar and make it as a means of international payment, and we are increasing the business use of the gold Dinar in trade with the three countries of West Asia, Morocco, Libya and Bahrain have expressed interest. He also proposes the use of e-Dinar system. To get around the movement of gold in physical form, in a hierarchy of international payments, and bilateral agreements.

2. Norwich, UK

Islamic population in Norwich, United Kingdom has long practiced the use of units of the currency of gold Dinar and silver Dirham as commercial transactions in their care. They have introduced a market named "Open Trade Relations". The free market is a practice that is very meaningful to Muslims especially because when the unit of Dinar and Dirham Right as practiced in a state of excess Dinar will be felt.
a. Bahrain
b. Cape Town, South Africa
c. Iraq
d. Jordan
e. Kuwait
f. Libya
g. Tunis
h. Turkey

The use of Dinar thorough application has not been fully implemented in many countries, including countries that are seen as the country with the largest Islamic economy such as Malaysia, UK and others. Because these countries are still difficult to transform the economy back on its namely 
a gold standard. This is because the Dollar has dominated so countries, especially Islamic countries is difficult to switch back because it has been focused on the Dollar.

\section{Riba Lost In Application Dinar}

Riba according to language is "azziyadah" or extra. Meanwhile, according to the terms, riba is additional load from property or capital by falsehood. Riba is divided into four, namely: usury Fadl, nasiah, qardh and jahiliyyah. Riba Fadl is riba arising from the exchange of similar goods is not the same as the proportion of gold in gold, silver and others. Second, nasiah usury is usury, which occurs because of the differences in delivery times as selling goods that are still unclear. Third, namely usury qardh arising from the activities of the presence of additional debt on debt repayments that have been required. Lastly is usury usury jahiliyyah that happened because of something gharar such as selling fruit still flowering.

If seen Rupiah have similarities or "illat" with gold and silver as equally become currency. So when gold will be exchanged for the currency, the conditions that must be met is in cash and the same amount. It is an absolute requirement to be met and if not then it will fall into the abyss of usury because of the excess weight in gold. Riba like this is usury Fadl. Likewise, if the gold was purchased indirectly delays submitter then there are gold and lead to riba nasiah (Dervish, 2014).

Therefore, the application of Dinar is not necessarily true regardless of usury although if done properly will eliminate the elements of riba but the wrong application may contribute to the usury. Because once again the terms of the redemption or sale of gold is the handover of cash. It's a condition that can not be bargained. So, usury on paper currency is not due to the fluctuating value. Riba on banknotes could happen because he as a medium of exchange in the purchase or gauge a person's wealth. And this also applies to gold and silver. So gold and silver can be contained usury.

\section{CONCLUSIONS AND IMPLICATION}

Application of the Dinar and Dirham as currency to stabilize the economy. Value of the Dinar and Dirham are likely to be stable and unchanged create balance in the movement of the economic curve. Not only stable but may hinder the use of the Dinar reduce financial dependence on its users against the Dollar. The application of this Dinar can change for the better the economic order although somewhat difficult in practice Application usage overall Dinar has not been fully implemented in many countries, including countries that are seen as the country with the largest Islamic economy such as Malaysia, UK and others. Because these countries are still difficult to transform the economy back on its namely a gold standard. This is because the Dollar has dominated so countries, especially Islamic countries is difficult to switch back because it has been focused on the Dollar.

The usury that can not be separated from the introduction of paper currency will be lost when a state has Dinar currency. But it is not impossible usury can occur in the use of the Dinar (gold). Therefore, the state must remain on guard in tackling it with sharia monetary operations.

\section{DAFTAR PUSTAKA}

Creswell, Jhon, W. 1994. Qualitative and Quantitative Approach California: Sage Publication. 
Daniar. 2016. Transmisi Kebijakan Moneter Syariah: Sebuah Analisa. Jurnal Ekonomi Syariah. Vol 1, No. 1.

Haerisma, Alvien Septian. 2011. Model Transaksi Dinar dan Dirham dalam Konteks Kekinian. Jurnal Holistik. Vol.12, No. 02.

Harahap, Darwis.2014. Analisis Stabilitas Dinar Emas dan Dolar AS dalam Demonisasi Rupiah. Jurnal Al-Iqtishad. Vol. VI, No. 2.

Hamidi, Luthfi. 2007. Gold Dinar Sistem Moneter Global yang stabil dan Berkeadilan, Jakarta: Senayan Abadi Publishing.

Hossain. 2010. Bank Sentral dan Kebijakan Moneter di Asia Fasifik. PT Rdja Grafindo Persada : Jakarta

Ibrahim, Ida Musdafia. 2014. Kaidah Fikih dalam Mengatasi Transaksi yang Mengalami Inflasi. Jurnal Ekonomi dan Hukum Islam. Vol. 4, No. 1.

Iswan, Rahmat Fauzi. 2008. Skripsi Peluang Dinar dalam Perdagangan Internasional. Universitas Negeri Syarif Hidayatullah Jakarta.

ISRA. Sistem Keuangan Islam Prinsip dan Operasi. PT Radja Grafindo Persada : Jakarta

Jamaluddin. Fiat Money. 2013.Masalah dan Solusi. Jurnal Akuntansi Multi Paradigma. Vol. 4, No. 2.

Masduqi, Zaenal. 2012. Penggunaan DinarDirham dan Fulus: Upaya Menggali Tradisi yang Hilang (Studi Kasus di Wilayah Cirebon). Jurnal Holistik. Vol. 13, No. 02 ..

Muhamad, Syaif. 2010. Skripsi Perbandingan Kestabilan dan Hubungan Volatilitas Nilai Tukar Dinar Emas, Dirham Perak dan Dolar $A S$. Universitas Negeri Syarif Hidayatullah Jakarta.
Saifudin. 2015. Pemikiran Ekonomi AlMaqrizi. Jurnal Ilmu Hukum dan Hukum Ekonomi Syariah. Vol. 1, No.01.

Saidi, Zaim. 2016. Hujah Terang Benderang untuk Mengembalikan Wang Suci Kita. dalam buku berjudul Telaah Kritis atas Fatwa Halalnya Uang Kertas, Jakarta: PIRAC, SEM Institute, Infid.

Shabri Abdul Majid, Muhammad. 2006. Analisis Terhadap Usaha Mendaulatkan Dinar Dan Dirham Sebagai Mata Uang Alternatif Dunia Islam. Jurnal Syariah.

Vadillo, Umar Ibrahim. 2001. Program Implementasi dalam buku berjudul Dinar Emas Solusi Krisis Moneter, Jakarta: PIRAC, SEM Institute, Infid

Yaacob, Salmy Edawati, dkk. 2011. Dinar Emas sebagai Mata Uang dan Komoditi di Beberapa Negara Terpilih. Jurnal Melayu. No.7. 